\title{
Environmental impact of geothermal power plants in Aydın, Turkey
}

\author{
Ersel Yilmaz ${ }^{1, *}$, and Mustafa Ali Kaptan $^{2}$ \\ ${ }^{1}$ Department of Biosystems Engineering, Adnan Menderes University, Aydın, Turkey \\ ${ }^{2}$ Department of Soil Science and Plant Nutrition, Adnan Menderes University, Aydın, Turkey
}

\begin{abstract}
Geothermal energy is classified as a clean and sustainable energy source, like all industrial activities, geothermal energy power plants (GEPP) technology has also some positive and negative effects on the environment. In this paper are presented by attent not only on environmental impacts of GEPP onto Büyük Menderes River and fresh water sources, which ere used for irrigation of agricultural fields from tousands of years in basin, but also on water quality contents like heavy metals and gases emition due to drilling and electricity producing technology of GEPP's. Aydın province is located in the southwestern part of the region and its city center has around 300000 population. The high geothermal potential of this region became from geographical location, which is held on active tectonic Alpine-Himalaya Orogen belt with active volcanoes and young faults. Since 1980 's to 2016 there is about $70.97 \%(662.75 \mathrm{MW})$ of installed capacity by according to the Mineral Research and Exploration General Directorate, there are totally 290 well licensed (540 explore licenses and 76 business licenses), and 31 geothermal powerplants purposely installed. Topic is important because of number of GEPP increased rapidly after 2012 to now a days to 36 in whole basin.
\end{abstract}

\section{Introduction}

Now a days Geothermal energy is called as clean and sustainable energy source although some bad samples in the world. Like all industrial activities in the world it has also positively and negatively effect on environment. The environmental effects may be temporary or irreversible and by include changes onto landscape and land use, by gases emissions into the atmosphere, on surfaces and subsurfaces water, noise, land subsidence, seismicity and solid-liquid rests and wastes.

\section{Geothermal Power Plants}

Energy is one of the fundamental and enticing requirements of the economic and social development of a country. It is one of the driving requirements. In this respect, "Energy Security" is a vital element of economic security and national security. Now a days, the energy consumed in the world is obtained from a large number of energy sources; fossil resources such as gasoline, natural gas and coal make up $87 \%$ of these resources [1]. In Fig. 1. is shown the destribution of types of energy consuption in hole countries in the world.

Geothermal power plants are one of the most important renewable energy sources listed in green energy status in the world. Geothermal power stations built in the framework of respect for nature, with nature's ability to provide closed-loop equipment is operating without damaging the structure of nature. Turkey is primary energy consumer, depends on energy sources such as oil, lignite, hard coal, and natural gas, which are import from other countries. That's why renewable energy potential can be seen as a great opportunity to substitute natural sources from an economic, environmental and social perspective [2].

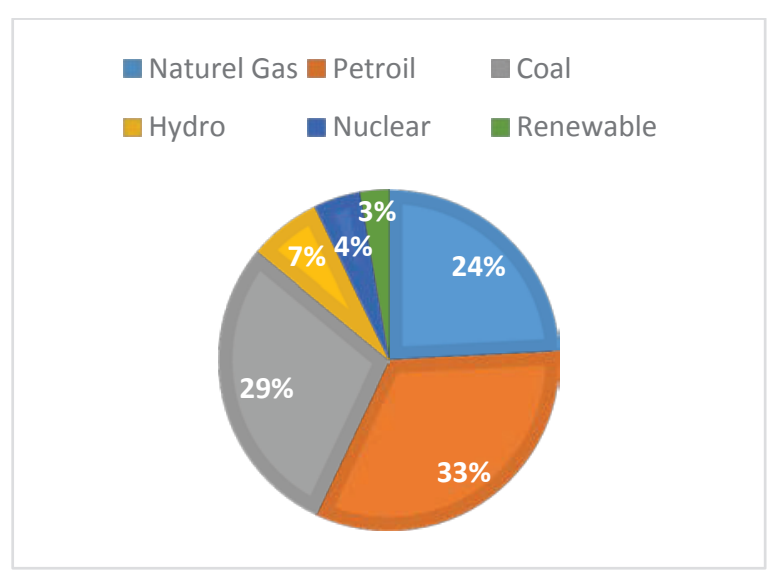

Fig. 1. Global primary energy consumption rates in 2016.

Total geothermal potential of Turkey is estimated around $30000 \mathrm{MW}$. In geothermal, Turkey has a proven $4000 \mathrm{MW}$ of resources over $20^{\circ} \mathrm{C}$ of which 600 to 1000 MW are high temperature fields able to produce electricity [3].

Turkey has huge potential as renewable energy. For

*Corresponding author: eyilmaz@adu.edu.tr 
example, geothermal potential is estimated to be 315 GWt and approximitly $5743 \mathrm{GWe}$, with the total installed power generation capacity in 2016 of 820.86 MWt (directly thermal used) and 100 MWe (converted to electricity). The high geothermal potential is the unique because of geographical location of the country, especially these region are located on the active tectonic Alpine-Himalaya Orogen belt with active volcanoes and young faults. Mostly of them are located in the Aegean and Central Anatolian region [2].

After 2009, numbers of geothermal energy power plants started to increase in Turkey by depending on electric energy needs of industry. Nowadays geothermal industry has achieved around 5\% annual growth rate in Turkey especially into west part and Central Anatolia. Especially in the Büyük Menderes and Gediz Graben's geothermal systems have been explored new geothermal fields by MTA and Turkish private sector [4].

Turkey initially in 2014 in the field of geothermal energy while in Kenya, including Indonesia and the Philippines, have entered into 21 new plants commissioned in about 610 MW. Worldwide, 23.5 billion $\mathrm{kWh} /$ year of electricity was produced in 2014 [2]. But Turkey has more devoloped then the others as produced electricity by using Geothermal Energy. This production $0.3 \%$ of the 73 million MWh / year, with a total capacity of $12800 \mathrm{MW}$, operating in 24 countries was conducted from geothermal energy. According to this indicator in $202014500-17600 \mathrm{MW}$ of geothermal energy sector, in 2030 is estimated to reach 2700030000 MW. $27 \%$ of total electricity production in the Philippines, $7 \%$ in California, $86 \%$ of the total heat energy needs are met from geothermal sources in Iceland [1].

Geothermal areas and power plants can be classified by different point of view, as according to temperature can be classified like below:

Table 1. Comparative description of different decentralized technologies [6].

\begin{tabular}{|c|c|c|c|c|c|}
\hline Technology & $\begin{array}{c}\text { Annual } \\
\text { generation } \\
\left(\text { TWhel } y^{-1}\right)\end{array}$ & $\begin{array}{l}\text { Capacity } \\
\text { factor }(\%)\end{array}$ & $\begin{array}{c}\text { Mitigation } \\
\text { Potential } \\
\left(\text { GtCO}_{2}\right)\end{array}$ & $\begin{array}{c}\text { Energy } \\
\text { requirements } \\
{\left[\left(\mathbf{k W h t h}(\mathbf{k W h e l})^{-1}\right]\right.}\end{array}$ & $\begin{array}{c}\mathrm{CO}_{2} \text { emissions } \\
{\left[\mathrm{g}(\mathrm{kWhel})^{-1}\right]}\end{array}$ \\
\hline Small hydro & $\approx 250$ & $\approx 50$ & $\approx 100$ & n.a. & 45 \\
\hline Wind & 260 & 24.5 & $\approx 450-500$ & 0.05 & $\approx 65$ \\
\hline $\begin{array}{l}\text { Solar- } \\
\text { photovoltaic }\end{array}$ & 12 & 15 & $25-200$ & $0.4 / 1-0.8 / 1$ & $\begin{array}{l}40 / 150- \\
100 / 200\end{array}$ \\
\hline $\begin{array}{l}\text { Concentrating } \\
\text { Solar }\end{array}$ & $\approx 1$ & $20-40$ & $25-200$ & 0.3 & $50-90$ \\
\hline Geothermal & 60 & $70-90$ & $25-500$ & n.a. & $20-140$ \\
\hline Biomass & 240 & 60 & $\approx 100$ & $2.3-4.2$ & $35-85$ \\
\hline
\end{tabular}

-Low enthalpy contains area $\left(20-70{ }^{\circ} \mathrm{C}\right)$

-Central enthalpy pitches area $\left(70-150{ }^{\circ} \mathrm{C}\right)$

-High enthalpy contains area $\left(>150^{\circ} \mathrm{C}\right)$

High Enthalpy for the production of electricity from geothermal water by using flash and binary methods, but problem is difficulties on re-injection because of rocks type and geography.

The environmental effects may be temporary or irreversible and include changes to landscape and land use, emissions into the atmosphere, surface and subsurface waters, noise, land subsidence, seismicity and solid waste.

Air and chemical pollution can be:

- Hydrogen Sulphide and its derivatives $\left(\mathrm{H}_{2} \mathrm{~S}\right)$ are also emitted, causing a bad smell and forming the acid rain causing compound $\mathrm{SO}_{2}$ in the atmosphere.

- Emitted carbon dioxide $\left(\mathrm{CO}_{2}\right)$ and $\mathrm{H}_{2} \mathrm{~S}$ are heavy gases and can lingering valleys causing increased pollution for local populations who lives closer to geothermal power plants

- Including radioactive element radon, toxic elements arsenic, mercury, ammonia, boron (highly toxic to plants) and other polluting heavy metals.
- Waste steam is sprayed over surrounding vegetation (usually rare species in geothermal areas), while waste water is either rejected (inducing earthquakes), or pumped into streams and lakes untreated, as treatment is considered too costly to be economically viable.

Dissolved minerals (e.g., boron, mercury and arsenic) contained in the liquid streams generated during the exploration, stimulation and production phases may poison surface or groundwater and harm local vegetation. It is therefore important to monitor wells during drilling and subsequent operations so that any leakage can be detected and managed rapidly.

Local weather changes leading to:

- influence on agriculture products,

- loss of rare thermophillic plants and algal growth,

- $\quad$ loss of scenery and tourism.

In Table 1 is presented comparative description of different decentralized technologies and special attention was paid on $\mathrm{CO}_{2}$ emission [6].

As of 2016, Turkey has 861 MW of installed capacity of geothermal power by numbers of 31 Geothermal power plants and produced 4213 GWh energy and $70.97 \%$ of 
this capacity (662.75 MW) is located in Aydın Region. Today by 36 geothermal power plants produce approximitly 5743 GWh energy in Turkey [7]. Geothermal power plants in international area had reached the $12800 \mathrm{MW}$ installed power capacity at the end of 2014 and Turkish geothermal sector which 4.79\% of the total is, power originating from geotermal energy. In Fig. 2 shown the temperatures contains of geothermal area of europe by help of determined of rocks temperature which are $5000 \mathrm{~m}$ depth [3].

In Fig. 3 there is shown that the geothermal areas and locations of geothermal power plants in hole Turkey for give information. Aydin province, with electricity generated from geothermal energy is to meet its own energy needs. The geothermal basin found in Aydın Province is the largest geothermal resource in Turkey and as a consequence the district is home for a number of geothermal electric power companies (Fig. 5).

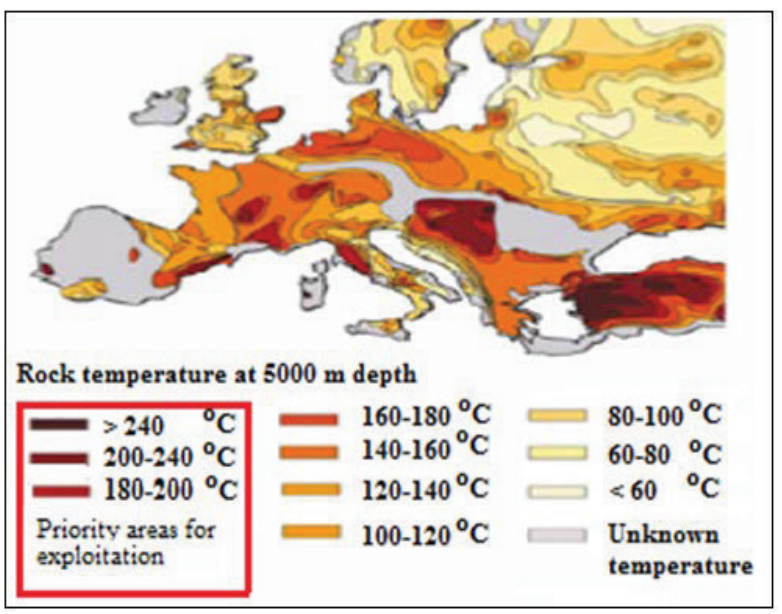

Fig. 2. Map of temperatures of geothermal area of European [3].

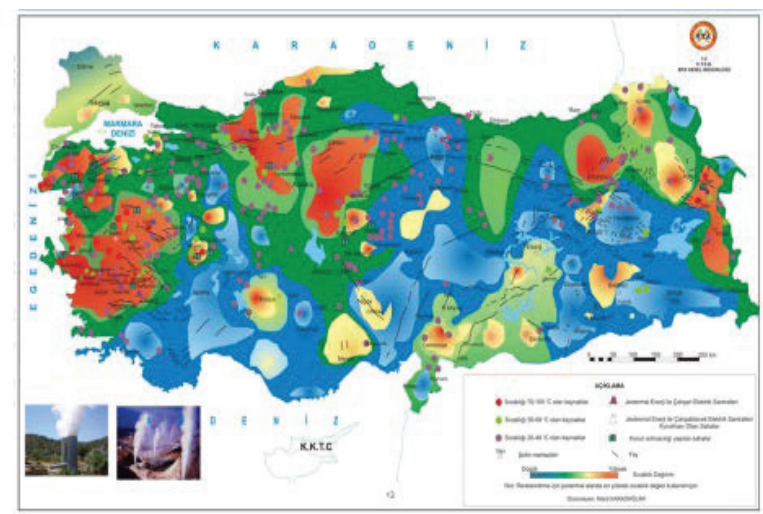

Fig. 3. Geothermal areas and locations of geothermal energy power plants in Turkey $[8,5]$.

The geothermal reservoir is large and the heat extraction limits for each plant are set at a level where the reinjected geothermal fluid is re-heated within the ground before being "used again". In this way, the hot water can be considered to be "cultivated" beneath the ground rather than "mined" [4]. In Fig. 4 is presented geothermal source areas in western Anatolia.

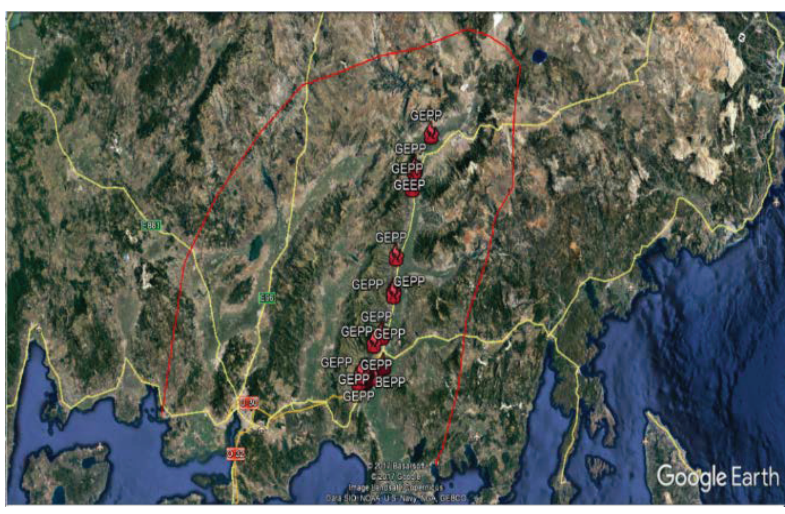

Fig. 4. Main geothermal areas of western Anatolia (Büyük and Küçük Menderes, Gediz basin).

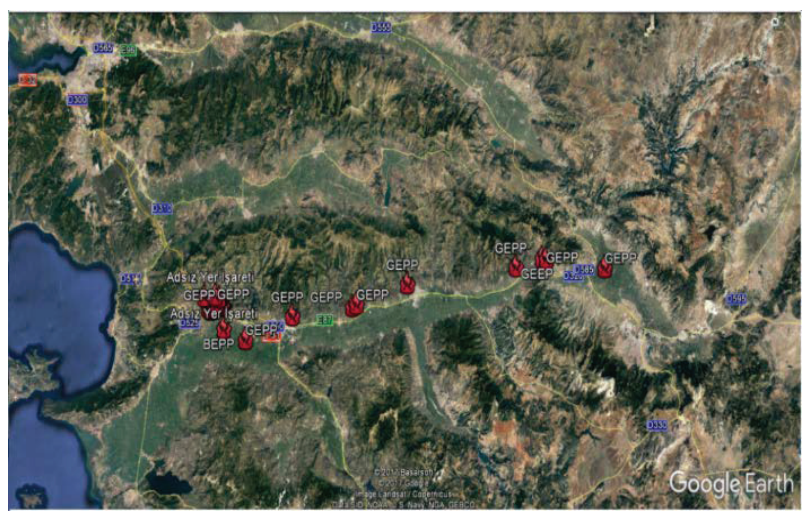

Fig. 5. Geothermal power plants locations which are produce electricity in Büyük Menderes Basin since 1986.

\section{Environmental aspects of geothermal power plants}

\subsection{Boron toxicity}

The many geothermal water sources were formed in the region as a result of the formation of the Büyük Menderes graben and high concentration of boron (B) in some water resources was reported [9]. The contamination of the hot-water resources with high boron consantration is one of the most important source the high concentration of $\mathrm{B}$ in irrigation water resources like well and surface water especially Büyük Menderes River. Also as presented in Table 2, average ratio of boron level is around $80 \mathrm{mgl}^{-1}$ in samples which is belongs to GEPP's wells, and there is a sign of one of source of boron in water resources. Therefore, this situation has become an important problem not only in Aydin region, but also for whole basin in the future. Boron is one of the micro nutrients required for normal growth of plants. Furthermore, boron is the only one micronutrient element which is non metal. Boron uptake greatly depends on transpiration by plant. It is known that the Boron toxicity showes negative effect on metabolic functions of the plant. The boron toxicity showes reduction on yield and yield components of plants owing to the plant tissues death, the active leaf area and photosynthetic activity reduction due to the high level of boron. The typical symptoms of boron 
toxicity show itself as chlorosis on the older leaves tips, and then following by the necrosis, finally the last phase

Table 2. Some chemical properties of geotermal waters in Germencik project research area, (avarage of last drilled geothermal wells, were analised in Lab. of ADU Agriculture Faculty) ( $\left.\mathrm{mg} \mathrm{l}^{-1}\right)$.

\begin{tabular}{|c|c|c|c|c|c|}
\hline EC $\left(\mu \mathrm{mho} \mathrm{cm}^{-1}\right)$ & Potassium $\left(\mathrm{K}^{+}\right)$ & Nitrite $\left(\mathrm{NO}_{2}{ }^{-1}\right)$ & Arsenic (As) & Iron $(\mathrm{Fe})$ & Aluminium (Al) \\
\hline 4650 & 105.9 & nd & 0.520 & 0.1060 & 0.256 \\
\hline pH & Lithium $\left(\mathrm{Li}^{+}\right)$ & Nitrate $\left(\mathrm{NO}_{3}{ }^{-1}\right)$ & Zinc (Zn) & Boron (B) & Copper (Cu) \\
\hline 8.15 & 5.99 & 33.21 & 0.044 & 80.41 & 0.028 \\
\hline Eh (mV) & Carbonate $\left(\mathrm{CO}_{3}\right)$ & Bromide $\left(\mathrm{Br}^{-1}\right)$ & Lead $(\mathrm{Pb})$ & Manganese (Mn) & Cobalt (Co) \\
\hline-64.1 & nd & nd & 0.033 & 0.038 & 0.018 \\
\hline Magnesium $\left(\mathrm{Mg}^{+2}\right)$ & $\begin{array}{c}\text { Bicarbonate } \\
\left(\mathrm{HCO}_{3}^{-1}\right)\end{array}$ & Phosphate $\left(\mathrm{PO}_{4}{ }^{-3}\right)$ & Cadmium (Cd) & Platinum (Pt) & Mercury (Hg) \\
\hline 5.90 & 2320 & nd & 0.038 & 0.025 & nd \\
\hline Calcium $\left(\mathrm{Ca}^{++}\right)$ & Chloride $\left(\mathrm{Cl}^{-1}\right)$ & Fluoride $\left(\mathbf{F}^{-1}\right)$ & Nickel (Ni) & Chromium (Cr) & Strontium (Sr) \\
\hline 7.26 & 300.30 & 11.70 & 0.025 & 0.014 & 2.670 \\
\hline Sodium $\left(\mathrm{Na}^{+}\right)$ & Sulphate $\left(\mathrm{SO}_{4}^{-2}\right)$ & $\mathrm{SiO}_{2}$ & Barium (Ba) & Titanium (Ti) & \\
\hline 1300 & 130.65 & 215.70 & 0.145 & 0.028 & \\
\hline
\end{tabular}

nd: not determined

show itself as a burnt leaves because of the boron is immobile in the plants (Fig. 6).

B toxicity sources are listed as follows soil B content, unconscious industrial waste management, thermal waters which are rich in soluble B and discharge of this thermal water to river, lake, irrigation waters and soils $[12,13]$. It is known that in some locations of northern Aegean and the territory of the Central and Eastern Anatolia have toxic levels of Boron in soils. The boron content in the soil of Aydin seems to be enough and high in some places [14]. According to data from the Mineral Research \& Exploration General Directorate, there are totally well 290 license (214 explore license and 76 business license) and 46 geothermal water resource purposely in Aydin region in 2012 [15]. The many of these resources drain its waste water to the Büyük

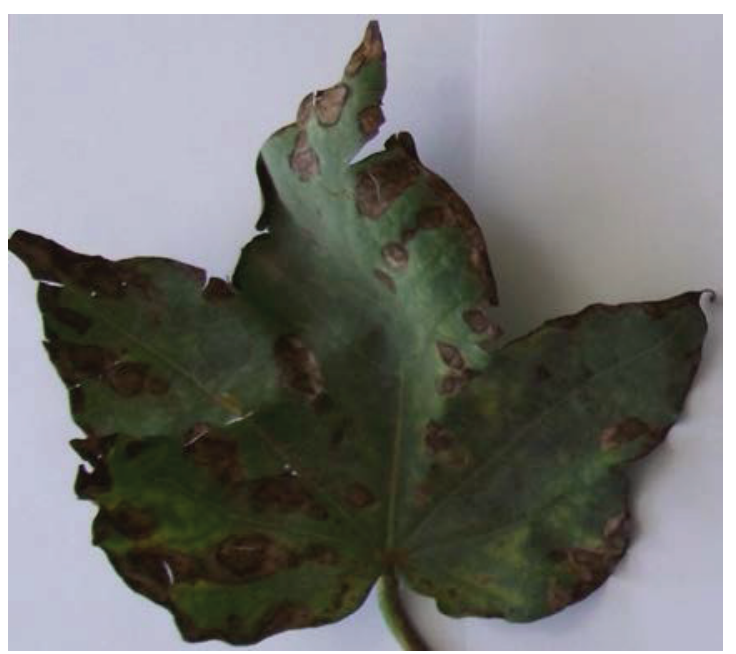

Menderes River. Thus waste water contaminates ground water and the boron content of the water sources for agricultural purposes is increasing [16]. Recent studies $[17,18,24]$ have shown that boron toxicity is a major problem at Büyük Menderes valley because of activity of geothermal power plants and their discharge of geothermal waste water due to drilling well to have effiancy and take it under control and into next stage due to holding electrical energy by using flash methode. Fluids emerging from some of these areas contain high boron concentrations and cause environmental problems for irrigation waters in agricultural areas where boron contaminates aquifers and soils [9]. Boron has accumulated in the plants more than required in the area [19].

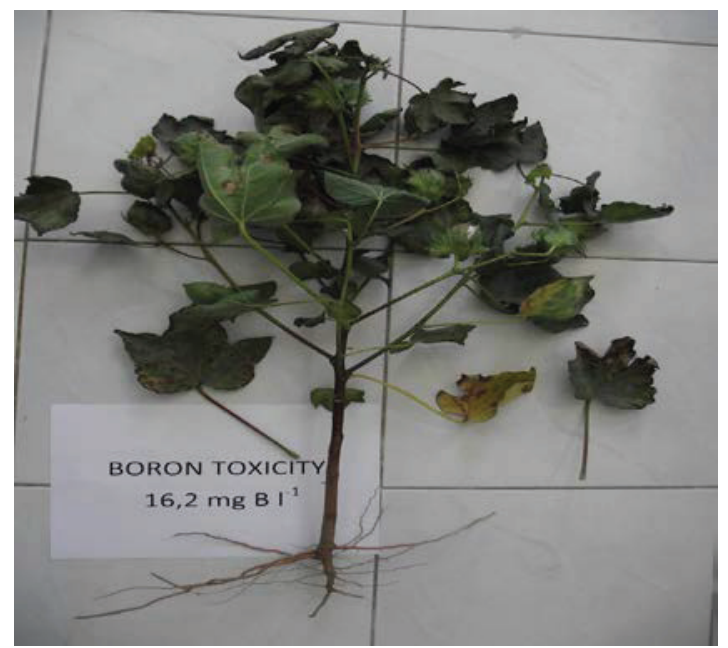

Fig. 6. Boron toxicity symptoms on cotton plants [17]. 
Table 3. Soil Boron Sufficiency Levels [20].

\begin{tabular}{|c|c|}
\hline $\mathbf{B}\left(\mathbf{m g ~ k}^{\mathbf{- 1}}\right)$ & Status \\
\hline $0-0.4$ & Severely Deficient \\
\hline $0.5-0.9$ & Deficient \\
\hline $1.0-1.4$ & Adequate \\
\hline $1.4-4.9$ & High \\
\hline$>5.0$ & Toxic \\
\hline
\end{tabular}

Table 4. Classifications of Boron for Irrigation Waters of Different Degree of Boron Tolerance [21].

\begin{tabular}{|c|c|c|c|}
\hline \multirow{2}{*}{ Classes } & Non tolerant Plants & Semi Tolerant Plants & Tolerant Plants \\
\cline { 2 - 4 } & \multicolumn{3}{|c|}{$\mathrm{mg} \mathrm{l}^{-1}$} \\
\hline Excellent & $<0.33$ & $<0.67$ & $<1.00$ \\
\hline Good & $0.33-0.67$ & $0.67-1.33$ & $2.00-2.00$ \\
\hline Permissible & $0.67-1.00$ & $1.33-2.00$ & $3.00-3.00$ \\
\hline Doubtful & $1.00-1.25$ & $2.00-2.50$ & $>3.75$ \\
\hline Unsuitable & $>1.25$ & $>2.50$ & \\
\hline
\end{tabular}

Boron toxicity can easily occurs especially arid and semi-arid regions in worldwide owing to the fact that the range of B deficiency and B toxicity is narrow (Table 3 ) $[10,11]$.

Kanber [22] in order to determine the pollution levels of some underground and surface waters in Aydin province, it has been reported that B contents of irrigation waters are between 0.474 and $8.234 \mathrm{mg}^{-1}$. In other study, Aydın and Seferoğlu [16] in order to determined boron contents of irrigation water, in Germencik region, between 0.33 and $6.41 \mathrm{mg} \mathrm{l}^{-1}$, where, underground hot water sources were located close to irrigation water.

\section{2 Heavy metal toxicity}

Heavy metals are not only natural components of the Earth's crust, but also important things for healthy of human and for sustainablity of nature and environment. They cannot be degraded or destroyed.

As In Table 2 point out in same table, there are heavy metals in water samples of drilled wells. These will be effected as cumulativly also on heavy metal toxicities in soils of basin and may be possible transfer to culture plants by irrigation water, which is also contamined, these rest-waste water can be contamine fresh water sources or surface water more than natural contamination before, which is used for irrigation, because of type of rocks and soil structures of region. To a small extent they enter our bodies by growing up of contaminated water's irrigated vegetables food, and via orginated animal food products, via drinking water and air. As trace elements, some heavy metals (e.g.copper, selenium, zinc) are essential to maintain the metabolism of human body, however, at higher concentrations they can be toxic [25].

There are point out in scientific stadies some determination of effect of heavy metals (e.g. Al, As, Cr, $\mathrm{Cd}, \mathrm{Pb}, \mathrm{Hg}, \mathrm{Ni}$ ) on living bodies in nature, about it's higher concentrations how they can be toxic and determined that heavy metals poisoning could result, for instance, from drinking-water contamination (e.g. lead pipes), high ambient air concentrations near emission sources, or intake by the food chain $[26,28]$.

\subsection{Microclimatic changes}

Because of GEPP's does not burn fuel like fossil fuel plants, they release virtually no air emissions. On emissions level have also influent technology. Influence of technologies on environmental impact is shown in Table 5.

Steam may have an impact on environment, ifluencing on microclimate. Local weather changes influence on agriculture products, and also loss of rare thermophillic plants such as olive trees.

The development of a geothermal areas can involve the removal of trees and brush to facilitate the installation of the power house, substation, well pads, piping, emergency holding ponds, etc. However, once a geothermal plant is built, reforestation and plantings can restore the area to a semblance of its original natural appearance, and can serve to mask the presence of buildings and other structures. 
Table 5. Influence of technologies on environmental impact [23].

\begin{tabular}{|c|c|c|c|}
\hline Description & Dry system & Flash steam & Binary cycle \\
\hline Emissions & $\begin{array}{c}\text { Highest } \\
\text { (low pressure exhaust steam is vented } \\
\text { to atmosphere }\end{array}$ & Moderate & $\begin{array}{l}\text { No emissions because of secondary } \\
\text { cycle loop is closed }\end{array}$ \\
\hline Fluid waste & $\begin{array}{c}\text { Moderate } \\
\text { e.g. } 65 \mathrm{~kg}(\mathrm{kWh})^{-1}\end{array}$ & $\begin{array}{c}\text { Highest } \\
\text { e.g. } 8 \mathrm{~kg}(\mathrm{kWh})^{-1}\end{array}$ & Lowest \\
\hline Application & $\begin{array}{l}\text { Very basic one, dry steam natural } \\
\text { hydrothermal reservoirs available }\end{array}$ & $\begin{array}{l}\text { Wherein geothermal fluids } \\
\text { contain low levels of } \\
\text { impurities }\end{array}$ & $\begin{array}{l}\text { Wherein geothermal fluids contain } \\
\text { low levels of impurities }\end{array}$ \\
\hline
\end{tabular}

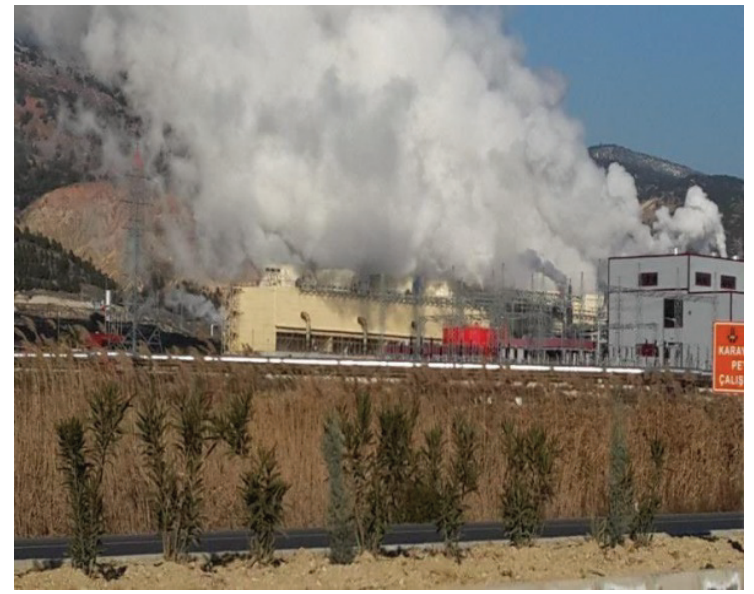

Fig. 7. Environmental impact of steam on local skale.

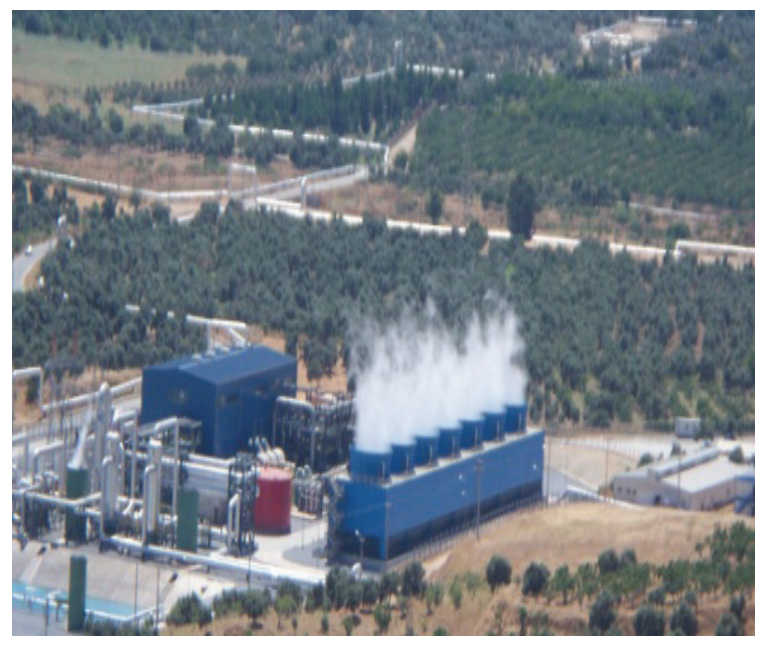

Fig. 8. An image of the cooling system of GEPP's.

Geothermal power plants shall give importance to geothermal district cooling. $70-80 \%$ of hot geothermal resources are located in Aydin and this area is extremely hot during the summer season and cooling is an important need. In Fig 7, 8 is shown about how impact of vapor of cooling systems on environment however to utilize cooling geothermally would be important in terms of the environment and decrease the dependance to fosil fuels and foreign countries.

\section{Conclusions}

This study was carried out in order to draw attention to the increasing problem of boron toxicity in the soil of Aydın region affected by wastes opened for authorized or unauthorized use for agricultural purposes and geothermal plants every day. Although geothermal energy is one of a clean and renewable resource, but it leads to B contaminated to irrigation water and soil during the electricity production or other process, by these way it may contain to drink water resources also, and it contains some gases which are important for gas emition for healthy of all living body. It is known that geothermal water contain not only boron but also heavy metals at different levels and concentrations. Although this study refers to the toxicity and pollution of boron caused geothermal water, it is also necessary to determine its heavy metal concentrations and pollutions on the other hand. Thats why in all stages should be organised (e.g. by lows, directives, articles, etc.) to controlled all wastes and restless in each countries which has geothermal sources for cover future of earth and life. Many of geothermal plants drain their waste water to the Büyük Menderes River, which is used to irrigation of agricultural area for thousands of years. Geothermal wastewater contaminated to ground water and boron content of the water sources for agricultural purposes opened is increasing. Some data shows concentration of boron level is $0.43-2.34 \mathrm{mgkg}^{-1}$ in soils and its toxicity is becoming increasingly an importance situation while the cotton growth in this region is very common and that's why it is believed that the severity and expand of the toxicity will become higher in the future.

Heavy metals are also dangerous like boron for human life, because they tend to bioaccumulate. As it known bioaccumulation means; that it's increase in the concentration of a chemical material which is in a biological organism over time, and compared to the chemical's concentration in environment. Compounds cumulatively increased in living things any time, they are taken up and stored faster than they are broken down as time (metabolized) or excreted. Still, food poisoning from heavy metals is very rare and in most cases only occurs after environmental pollution. As we known the most important example of such an environmental pollution occurred in Japan between 1932 and 1955 [26, $27,28]$. As we categorized general damage of heavy metals can be say about its damages, cause of their high concentration in human body like below;

-They damage to the central nervous system, 
-Dementia

-Loss of memory

-Listlessness

-Severe trembling

-Alzheimer's disease

-Lung embolism

-Respiratory failure

-Birth defects

-Asthma and chronic bronchitis

-Allergic reactions such as skin rashes, mainly from jewelry

-Heart disorders, and more [25-28].

As a result, human should change GEPP's electricity producing technology, from the type of flash steam system, however its called green and sustainable energy to the other tyeps of clean and green systems, for to not have more gain by reselling old technologies to the developing or undeveloped countries and should have produce new technologies for its cooling needs to not cooling by thrue out vapor to atmosphere and should cover natural environment as possible as for new generations.

\section{References}

1. BP Energy outlook to 2035, 96, (2016)

2. TP crude oil and natural gas sector report, May, 17, (2016)

3. T. Kaya, TPIC and METU, An overview on Drilling and Geothermal Energy Projects in Turkey, GRC Annual Meeting International Luncheon Reno, NV, USA, 16 (2012)

4. O. Mertoglu, S. Simsek, N. Basarir, Proceedings World Geothermal Congress 2015, 19-25 April Melbourne, Australia, 16 (2015)

5. R. Ilgar, Ekolojik Bakışla Jeotermal Kaynaklara Dualist Yaklaşım, (Elektronik Sosyal Bilimler Dergisi, 4, 13 88-98, Çanakkale, 2005)

6. A.A. Bazmi, G., Zahedi, Renewable Sustainable Energy Rev. 15, 8, 20 (2011)

7. www.enerjiatlasi.com/jeotermal/geotermal energy powerplants, (07.05.2017)

8. www.mta.gov.tr (10.03.2017)

9. Ü. Gemici, G. Tarcan, J. Volcaol. Geotherm. Res 116, 215-233 (2002)

10. F.M. Eaton, J. Agric. Res. 69, 237-277 (1944)

11. U.C. Gupta, Y.W. Jame, C.A. Canadian J. Soil Sci. 65, 381-409 (1985)

12. B. Cartwright, B.A. Zarcinas, A.H. Mayfield, Aust. J. Soil Res. 22, 261-272 (1984)

13. R.O. Nable, G.S. Banueuels, J.G. Paull, Plant Soil 193, 181-198 (1997)

14. Anonymous, Tarım-Bor Araştırma ve Uygulama Program1, http://www.boren.gov.tr/tr/ isbirlikleri/ tarim-bor-arastirma-ve-uygulama-programi, (20.02.2015)

15. Anonymous, Yazılı Soru Önergesi (7/8210). TBMM Başkanlığı, 18.06.2012 tarih ve A.01.0.GNS.0.10. 02.00-72340 say1l yazıs1 (2014) http://www.tbmm.gov.tr/develop/owa/

yazili_soru_sd. sorgu_baslangic (13.08.2014)

16. G. Aydın, S. Seferoğlu, Aydın Yöresinde Kullanılan Bazı Sulama Sularının Bor konsantrasyonunun Bitki Beslenmesi ve Toprak Kirliliği Açısından İncelenmesi. TOGTAG-1767, Aydın (1999)

17. M.A. Kaptan, Pamukta (Gossypium hirsutum L.) Bor Toksisitesi ve Humik Madde Uygulamasının Etkileri. Adnan Menderes Üniversitesi, Fen Bilimleri Enstitüsü, Doktora Tezi, Aydın (2013)

18. M. Aydın, M.A. Kaptan, Z. Dalkılıç, Relationship between fruit cracking and nutritional status of fig (Ficus caricaL. cv. sarilop) plantations in the lowland of Aydın, Turkey. International Soil Fertility Congress, Germany (to be published).

19. C. Koç, Environ. Prog. Sustainable Energy 30, $347-$ 357 (2011)

20. B. Wolf, Soil Sci. Plant Anal. 2, 263-374 (1971)

21. M.D. Thorne, H.B. Peterson, Irrigation Soil (2nd Ed., The Blackinston Co. Inc, NewYork, 1954)

22. P. Kanber, Aydın İli Bazı Yeraltı ve Yerüstü Su Kaynaklarının Kirlilik Durumlarının Belirlenmesi (ADÜ. FBE. Yüksek Lisans Tezi, Aydın, 2007)

23. R. Banos, F. Manzano-Agugliaro, F.G. Montoya, C. Gil, A. Alcayde, J. Gomez, Renewable Sustainable Energy Rev. 15, 1753-1766 (2010)

24. M.A. Kaptan, M. Aydın, Z. Dalkılıç, Agro Life Sci. J. 1, 3, 75-80 (2014)

25. http://www.lenntech.com/periodic/elements, (03.06.2017)

26. http://www.food-info.net/tr/index.htm, (03.06.2017)

27. http://www.who.int/emergencies/famine/en/, (03.06.2017)

28. C. Bakar, A. Baba, 1.Tıbbi Jeoloji Çalıştayı, J. 1, 162-185, (2009) 